Recorregut de recerca geològica i geoambiental per les comarques de l'Anoia (Alta Segarra), Segarra i Urgell: des de la Panadella a Estaràs, les Oluges, Tarroja de Segarra, Agramunt i al Pilar d'Almenara

Josep Maria Mata-Perelló

Joaquim Sanz Balagué

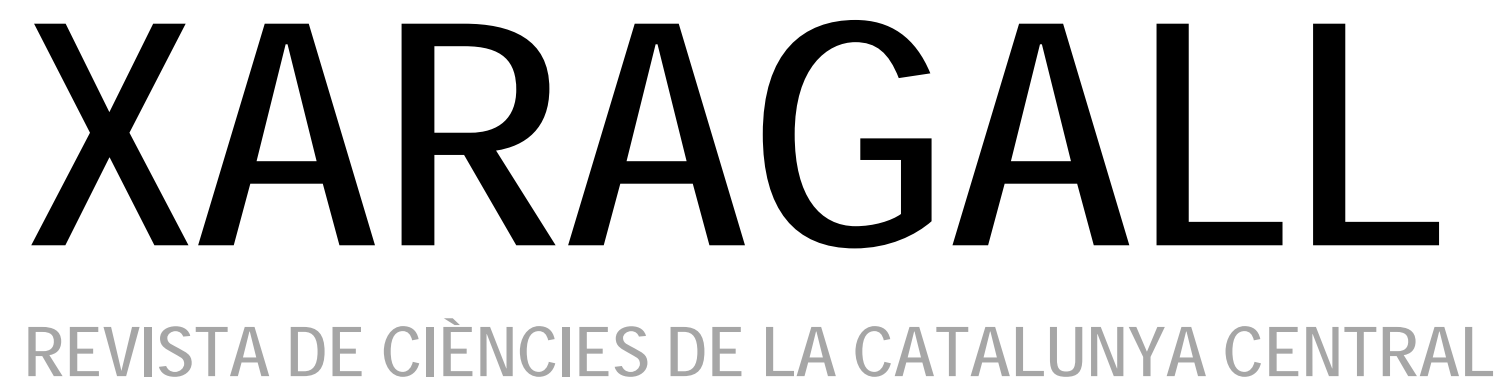

n. 2

FEBRER 2015 


\title{
RECORREGUT DE RECERCA GEOLÒGICA I GEOAMBIENTAL PER LES COMARQUES DE L'ANOIA (ALTA SEGARRA), SEGARRA I URGELL: DES DE LA PANADELLA A ESTARÀS, LES OLUGES, TARROJA DE SEGARRA, AGRAMUNT I AL PILAR D’ALMENARA
}

\author{
Josep Maria Mata-Perelló \\ Museu de geologia Valentí Masachs, Escola Politècnica Superior d'Enginyeria de Manresa \\ (EPSEM), Universitat Politècnica de Catalunya · BarcelonaTech (UPC), 08272 Manresa, Spain
}

Joaquim Sanz Balagué

Departament d'Enginyeria Minera i Recursos Naturals (EMRN), Escola Politècnica Superior d'Enginyeria de Manresa (EPSEM), Universitat Politècnica de Catalunya - BarcelonaTech (UPC), 08272 Manresa, Spain

Paraules clau: Depressió Geològica de l'Ebre, Materials terciaris, Materials quaternaris, Patrimoni miner

\begin{abstract}
Resum
Itinerari realitzat el 22 de març de 2014. En aquesta ocasió, es realitzarà un recorregut geològic que discorrerà en la seva totalitat per diferents indrets de la Depressió Geològica de I'Ebre; i més concretament pels sectors corresponents a la seva Depressió Central.

D'aquesta manera, tot el recorregut transitarà entre afloraments dels materials terciaris (de I'Oligocè) i quaternaris que reblen aquesta depressió. Així, durant els trams inicials del recorregut, anirem trobant afloraments que corresponen als materials de la Formació Tàrrega, situant-se íntegrament dintre del Complex Lacustre de la Segarra. Així, veurem terrenys calcolutitics, carbonatats, argilosos i lignits, fonamentalment, al llarg de tot el recorregut de I'itinerari. Després, començarem a trobar afloraments dels materials de la Formació Urgell, d'aquest mateix complex. I, finalment, a la darrera aturada trobarem afloraments guixosos de la Formació Barbastro.
\end{abstract}

Per altra banda, el recorregut transitarà inicialment per la comarca de l'Anoia, pels sectors septentrionals i segarrencs de la comarca. Després, (en arribar a la Tallada) penetrarà a la comarca de la Segarra, per entrar més tard a la de l'Urgell (entre Mont-roig de Segarra i Bellver d'Ossó), per on finalitzarà. Al llarg d'aquest recorregut, anirem seguint, amb algunes intermitències la vall del riu Sió.

Xaragall.2015 n.2 | Recorregut de recerca geològica i geoambiental per les comarques de l'Anoia (Alta 


\section{Objectius fonamentals}

Els objectius fonamentals que es pretenen aconseguir en aquest itinerari, es poden concretar en els següents aspectes generals:

1. Observació i descripció dels materials terciaris (exclusivament del Paleogen, i més concretament de I'Oligocè) de la Depressió Geològica de l'Ebre (i més exactament de la seva Depressió Central). Així, el recorregut de l'itinerari discorrerà inicialment entre els afloraments del materials la Formació Tàrrega, dintre d'aquesta formació, es veuran afloraments eminentment carbonatats, de calcolutites, calcàries, argiles i lignits. Posteriorment, es trobaran afloraments de les calcolutites i gresos lleugerament rogencs de la Formació Urgell. I, finalment, a la fi del recorregut, es trobaran afloraments de les calcolutites blanquinoses i dels guixos de la Formació Barbastro.

2. Observació de les estructures locals de la Depressió Geològica de l'Ebre, al Ilarg del recorregut de l'itinerari. Dintre d'aquestes estructures, ens fixarem en la Fosa Tectònica de Pujalt - Ferran i en I'Anticlinal de la Serra d'Almenara.

3. Observació de les diferents explotacions mineres que anem trobant al llarg del recorregut de l'itinerari, especialment de les calcàries (pels voltants de Conill i de Sant Ramon, entre altres indrets).

4. Observació, si s'escau de les restauracions dutes a terme en les explotacions anteriors, de cara a recuperar el medi natural malmès

5. S'observaran, al llarg de tot el recorregut, els diferents elements relacionats amb el Patrimoni Geològic i Miner. Així, a més a més de les estructures tectòniques esmentades a I'apartat 2, veurem la Font de Gaver, per on neix el riu Sió.

\section{Antecedents}

Pel que fa al recorregut del tram inicial existeixen un parell d'antecedents; es tracta de: Mata Perelló (2007 i 2014). Pel que fa al tram final, hi ha un altre antecedent nostre; concretament: Mata Perelló (1999). Tret d'aquests, no en coneixem cap altre antecedent bibliogràfic.

Pel que fa a l'estructura geològica de la zona per la qual discorre l'itinerari, farem esment dels treballs de: GUIMERÀ et altri (1982) i de RIBA et altri (1976). També farem esment d'un treball nostre: Mata Perelló (1985).

Tots aquests treballs referenciats, i d'altres, figuren esmentats per ordre alfabètic a l'apartat dedicat a la BIBLIOGRAFIA.

Xaragall.2015 n.2 | Recorregut de recerca geològica i geoambiental per les comarques de l'Anoia (Alta 


\section{Recorregut de l'itinerari}

El recorregut de l'itinerari discorrerà inicialment per la comarca d'Anoia. I ho farà per l'entorn de les poblacions de la Panadella i de Montmaneu. En aquesta part del recorregut es transitarà per les carreteres locals: BV - 2234 i B - 221 (pels voltants de la Panadella) i finalment per la B- 100 (anant cap a Montmaneu). En aquest tram, haurem fet dues aturades.

Tot seguit s'entrarà a la comarca lleidatana de la Segarra, circulant-se pels voltants de la Tallada i de Sant Guim de Freixenet. Posteriorment, continuarem per la carretera local LV 1005, anant cap a Sant Domi i cap a Gaver. Per on farem una nova aturada.

Després, el recorregut es dirigirà per un bon camí de terra cap a Pujalt, circulant ara per la comarca de I'Alta Segarra (Anoia), des d'on s'anirà cap a Ferran i cap a Sant Ramon, després de retornar a la Segarra pròpiament dita. En aquesta part del recorregut, s'hauran fet dues noves aturades, circulant per les carreteres B - 102 i N - 141a. Posteriorment, s'anirà per aquesta darrera carretera cap a les Oluges, fent-se una nova aturada, entre les dues darreres poblacions.

Més endavant, per un camí de terra, s'anirà cap a Castellnou d'oluges, Malgrat, la Prenyalosa i Tarroja de Segarra, seguint el riu Sió, per la seva riba dreta. En aquest tram, es farà una nova aturada. I posteriorment, es continuarà cap als pobles de Sedó, Riber, Hostafrancs i Concabella, seguint la carretera local $L-324$. En aquest tram es farà una nova aturada.

Ara, a partir d'aquí, es continuarà (anant sempre cap a ponent) seguint el riu Sió, però ara per la carretera L - 304. Així, ara es passarà pels pobles de: Ratera, les Pallargues i Mont-roig de Segarra. Poc després d'aquest poble s'entrarà a la comarca de l'Urgell, seguint poc després per la carretera $L$ - 303, passant ara per Bellver d’Ossó (o Bellver de Sió), Ossó de Sió, Castellnou d'Ossó, Puigvert d’Agramunt i Agramunt. En aquest tram es faran dues noves aturades.

I, finalment, des d'aquest darrer poble (la capital de la comarqueta de la Ribera de Sió), ens caldrà seguir per la carretera local LV - 3231 (la qual es dirigeix cap a Tornabous). En arribar a les immediacions del Pilar d'Almenara, es farà la darrera aturada, finalitzant el recorregut d'aquest itinerari.

\section{Advertiments previs}

Com en altres recorreguts de RECERCA GEOLÒGICA I MINERALÒGICA... si es disposa del temps suficient, poden efectuar-se passant per totes les parades i filloles. En cas contrari, recomanem prescindir de les anomenades PARADES - CONDICIONALS.

També cal tenir en conte que en algunes parts del recorregut, caldrà fer trams per camins de terra; això si molt pocs i curts, per la qual cosa serà millor fer-los a peu, o buscar informacions sobre l'estat dels camins. En aquest recorregut farem dos trams per camins de terra: de Gaver a Pujalt; i també de les Oluges a Tarroja de Segarra.

Cal tenir, com sempre, una cura molt especial de respecte a la natura, al llarg de tot el recorregut de l'itinerari, i també fora d'ell.

Xaragall.2015 n.2 | Recorregut de recerca geològica i geoambiental per les comarques de l'Anoia (Alta 


\section{Descripció de l'itinerari}

Com de costum, estructurarem el recorregut de I'itinerari en una sèrie de PARADES, que anirem veient. En cadascuna d'aquestes aturades farem un breu comentari (geològic 0 mineralògic, segons s'escaigui). En cada cas indicarem, entre parèntesi, el full topogràfic on es troba l'aturada. En aquest cas, el recorregut de l'itinerari s'inclourà dintre dels següents fulls, del "Mapa Topográfico Nacional", realitzats a l'escala 1:50.000 per I'"I.G.C. de España": 360 (o d'Agramunt, tot i que abans era el de Bellvís), 361 (o de Cervera, encara que abans es coneixia com a full de Guissona) i 390 (o full de Tàrrega, encara que abans era conegut com el full de Cervera). Tanmateix, si s'escau, es pot utilitzar els Mapes Topogràfics Comarcals d'Anoia, la Segarra i l'Urgell, editats per l'Institut Cartogràfic de Catalunya. Així doncs, la relació de les aturades, que composen el recorregut d'aquest itinerari és la següent.

\subsection{Parada 1. PEDRERA DE CALCÀRIES DE LA PANADELLA - CARBASSí, (la Panadella, terme municipal de Montmaneu, comarca de I’Anoia). (Full 390).}

El recorregut l'iniciarem prop del poble de Carbassí; en realitat, entre aquesta localitat i la de la Panadella, a la carretera BV - 2234, que uneix els dos pobles. En aquest indret hi ha unes antigues explotacions de calcàries. Aquí farem la primera de les aturades d'aquest itinerari, a uns $2 \mathrm{Km}$ de cada un dels dos pobles.

En aquest indret afloren uns nivells carbonatats calcaris, les anomenades calcàries de Montmaneu - la Panadella. Al respecte, cal recordar que quests materials formen part de Formació Tàrrega, constitueixen aquí el Complex Al-luvial de la Segarra. Aquestes calcàries, per canvi lateral de fàcies passen a la Formació Calaf, la qual es troba amplament representada més cap al NE d'un ara ens trobem. Aquests darrers materials són els que es troben al Port de la Panadella, on constitueixen una suau cinglera, una clara "cuesta. Aquesta cinglera constitueix la divisòria d'aigües entre la vall del Segre, i la de I'Anoia. Així, per sota de les calcàries, cap al Nord, neixen el riu d'Ondara i el riu Corb, tributaris del Segre. Mentre que cap al Sud ho fa el riu Anoia, tributari del Llobregat.

Per altra banda, en aquest lloc, on fem la present aturada, hi ha una important explotació a "cel obert" dels nivells carbonatats dels quals hem acabat de parlar. Aquestes calcàries, en bona part s'utilitzen $\mathrm{cm}$ a àrids. (fotografia 1 ). 


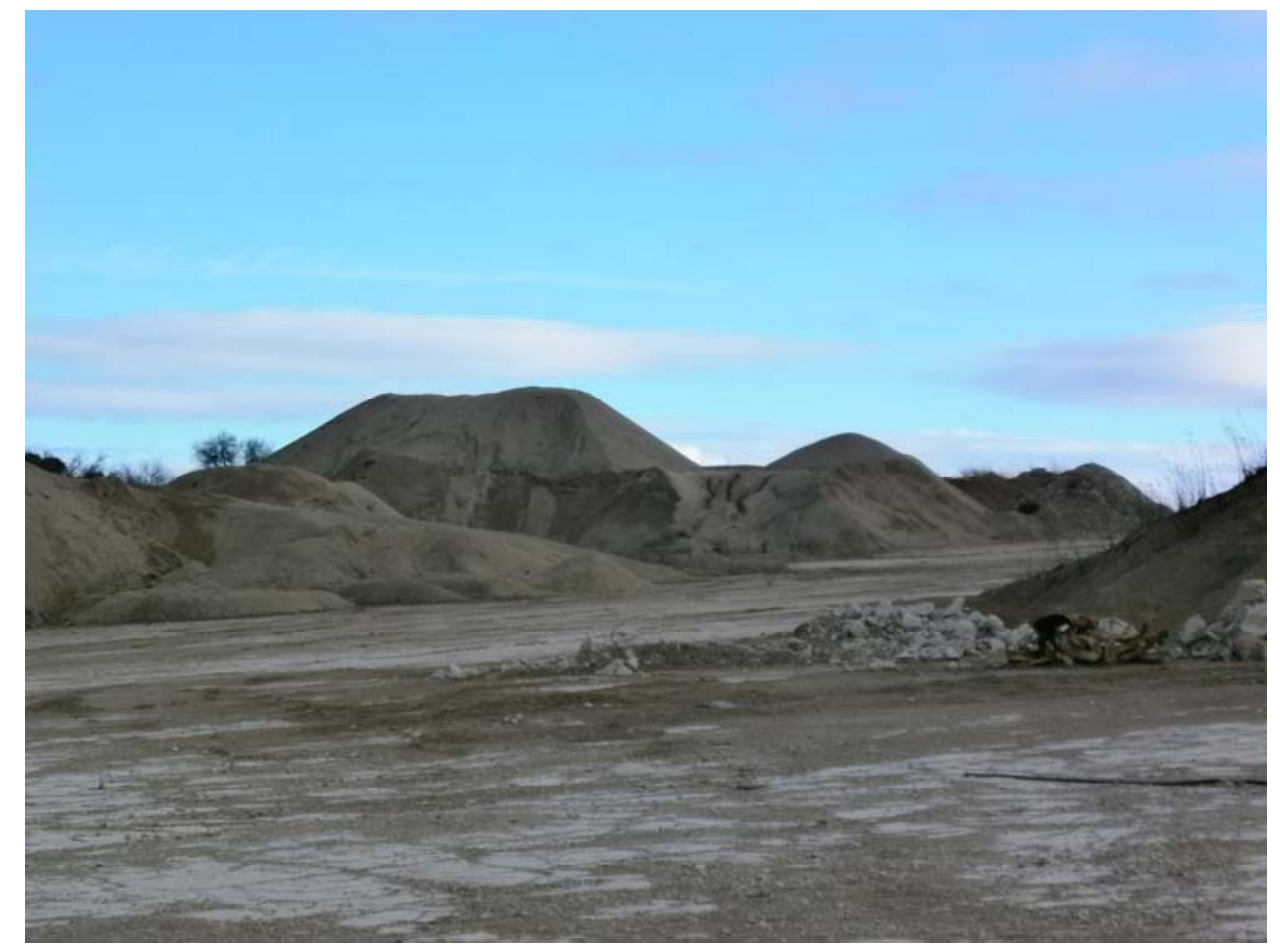

Fotografia 1. Aflorament i explotació de les calcàries de la Panadella. Pedrera de Carbassí - la Panadella

\subsection{Parada 2. IMMEDIACIONS DE MONTMANEU, CARRETERA A CALAF, B - 100, (terme municipal de Montmaneu, comarca d'Anoia). (Full 390).}

Després de fer l'aturada anterior, ens caldrà agafar la carretera local BV - 2234, la qual es dirigeix cap a la Panadella, tot i que troba abans la carretera $B$ - 221. En arribar-hi, caldrà creuar la carretera nacional $\mathrm{N}$ - IIA i I'Autovia $\mathrm{A}$ - 2. Així, ens caldrà agafar la carretera local $\mathrm{B}$ - 100. Per aquesta, aviat arribarem a Montmaneu, des d'on ens caldrà continuar cap a l'ENE. Poc després de sobrepassar el darrer poble esmentat, podem fer una nova aturada. Així, haurem recorregut poc més de $5 \mathrm{Km}$ des de l'inici del recorregut.

En aquest recorregut, hem anat trobant afloraments dels materials carbonatats que pertanyen a la Formació Tàrrega. Aquests són els materials que es troben a l'indret on farem aquesta aturada.

Per altra banda, en aquest recorregut estem situats a la part més alta de la taula de la Panadella. Aquesta és una divisòria d'aigües. Prop d'on som neix el riu Sió, afluent del Segre, que se'n va cap a ponent. I també del riu Panadella, (afluent de I'Anoia), que se'n va cap a llevant. Per d'altra banda, des d'aquest indret, es pot gaudir d'una bona observació de les valls del dos rius.

Xaragall.2015 n.2 | Recorregut de recerca geològica i geoambiental per les comarques de l'Anoia (Alta 


\subsection{Parada 3. FONT DE GAVER, NTIGA PEDRERA DE SEGUR, (Gaver, terme municipal d'Estaràs, comarca de la Segarra). (Full 361).}

Després de realitzar la parada anterior, cal continuar cap a l'ESE per la carretera B - 100. Així aviat es deixarà la comarca de l'Anoia, passant momentàniament a la comarca de la Segarra. Aviat es passarà per la Tallada i posteriorment per les immediacions de Sant Guim de Freixenet. Des d'aquí, ens caldrà continuar cap el Nord, seguint ara la carretera local LV 1005. Així, arribarem primer a Sant Domin i posteriorment a Gaver. En aquest darrer poble farem una nova aturada, després de recórrer uns $8 \mathrm{Km}$, des de la parada anterior, aproximadament.

En aquest recorregut, hem anat trobant afloraments inicialment els materials esmentats a les aturades anteriors; és a dir dels materials carbonatats de la Formació Tàrrega. Aquests són els materials que hi ha a l'indret de l'aturada. Aquests materials formen part del Complex Al.luvial de la Segarra. Es troben formats per nivells de calcolutites i gresos, de tonalitats grisenques. Precisament, sota del poble es fan força palesos els nivells eminentment carbonatats. (fotografia 2).

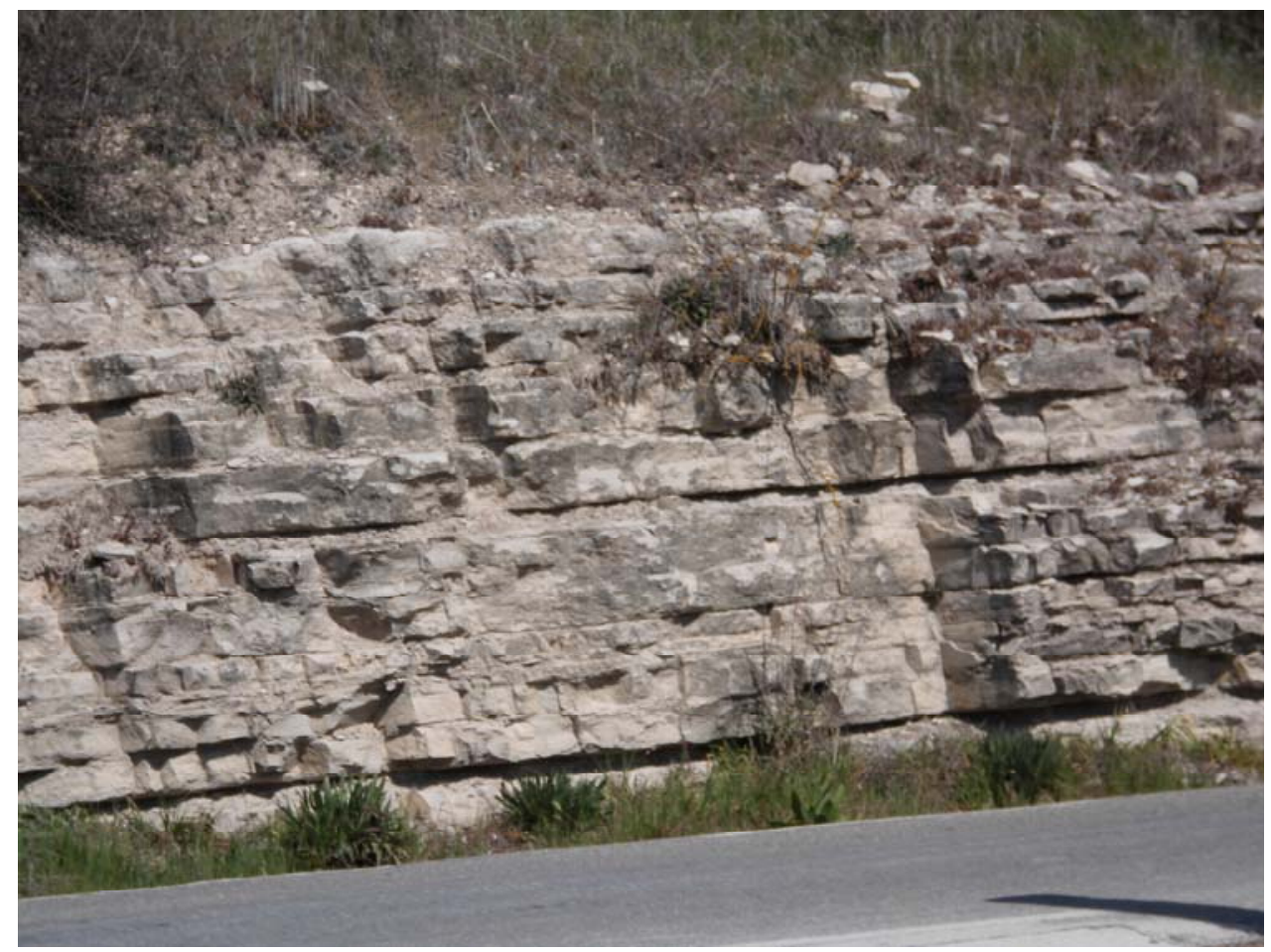

Fotografia 2. Aflorament de les calcàries de la Formació Tàrrega a Gaver

Xaragall.2015 n.2 | Recorregut de recerca geològica i geoambiental per les comarques de l'Anoia (Alta 
Per altra banda, a l'indret de la present aturada (per on també afloren els nivells carbonatats anteriors) hi ha un interessant naixement d'aigua. Es tracta del naixement del riu Sió, un dels principals afluents del Segre per la seva banda esquerra (per on els rius són poc cabdalosos $i$ poc importants). Així, es pot considerar que aquest lloc és un LIG (Lloc d'Interès Geològic). (fotografia 3).

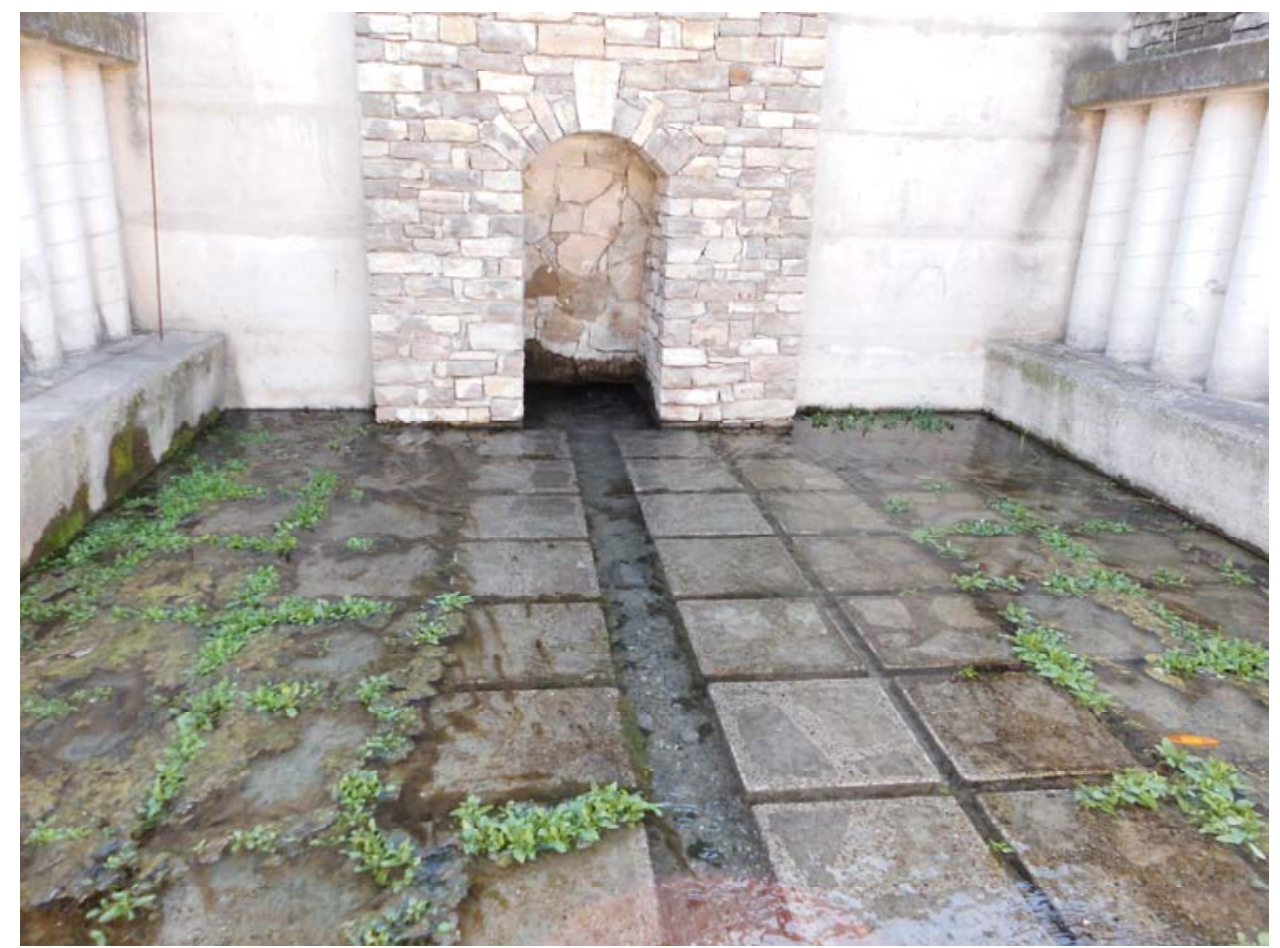

Fotografia 3. Font de Gaver. Naixement del riu Sió a Gaver

Tot i així, aquest indret es troba quasi totalment antropitzat i modificat. Encara i així, es pot considerar un LIG, com hem dit anteriorment. 


\subsection{Parada 4. CRUİLLA DE LA CARRETERA DE PUJALT AMB LA CARRETERA NACIONAL N - 141a, (terme municipal de Pujalt, comarca d'Anoia, Alta Segarra Calafina). (Full 391).}

Després de fer la parada anterior, cal continuar per un camí de terra que es va dirigint cap el NNE, anant en uns $5-6 \mathrm{Km}$ cap el poble de Pujalt. En arribar-hi, ens caldrà agafar la carretera $\mathrm{B}-102$. Per aquesta s'arribarà a la carretera nacional $\mathrm{N}-141 \mathrm{a}$. En arribar a la cruïlla, podem fer una nova aturada. Així, des de l'anterior, haurem recorregut uns $8 \mathrm{Km}$, aproximadament.

En aquest recorregut, hem deixat la comarca de la Segarra, per a entrar de nou a la de I'Anoia; tot i que ara estem dintre de la denominada Segarra Calafina o Alta Segarra; és a dir, en sentit ampli continuem dintre de la Segarra.

Per altra banda, en aquest recorregut, hem continuat trobant afloraments dels materials carbonatats de la Formació Tàrrega. És a dir, continuem estant dintre del anomenat Complex Al-luvial de la Segarra. Així, per arreu es fan palesos els afloraments dels nivells carbonatats i dels calcolutítics.

Per d'altra banda, en aquest indret, poc abans d'arribar a la cruïlla amb la carretera nacional $\mathrm{N}$ - 141a, hem sobrepassat una vall lineal, molt ben definida. Creiem que es tracta d'un interessant "gravén", que podríem denominar Fosa Tectònica de Ferran Pujalt. (fotografia 4).

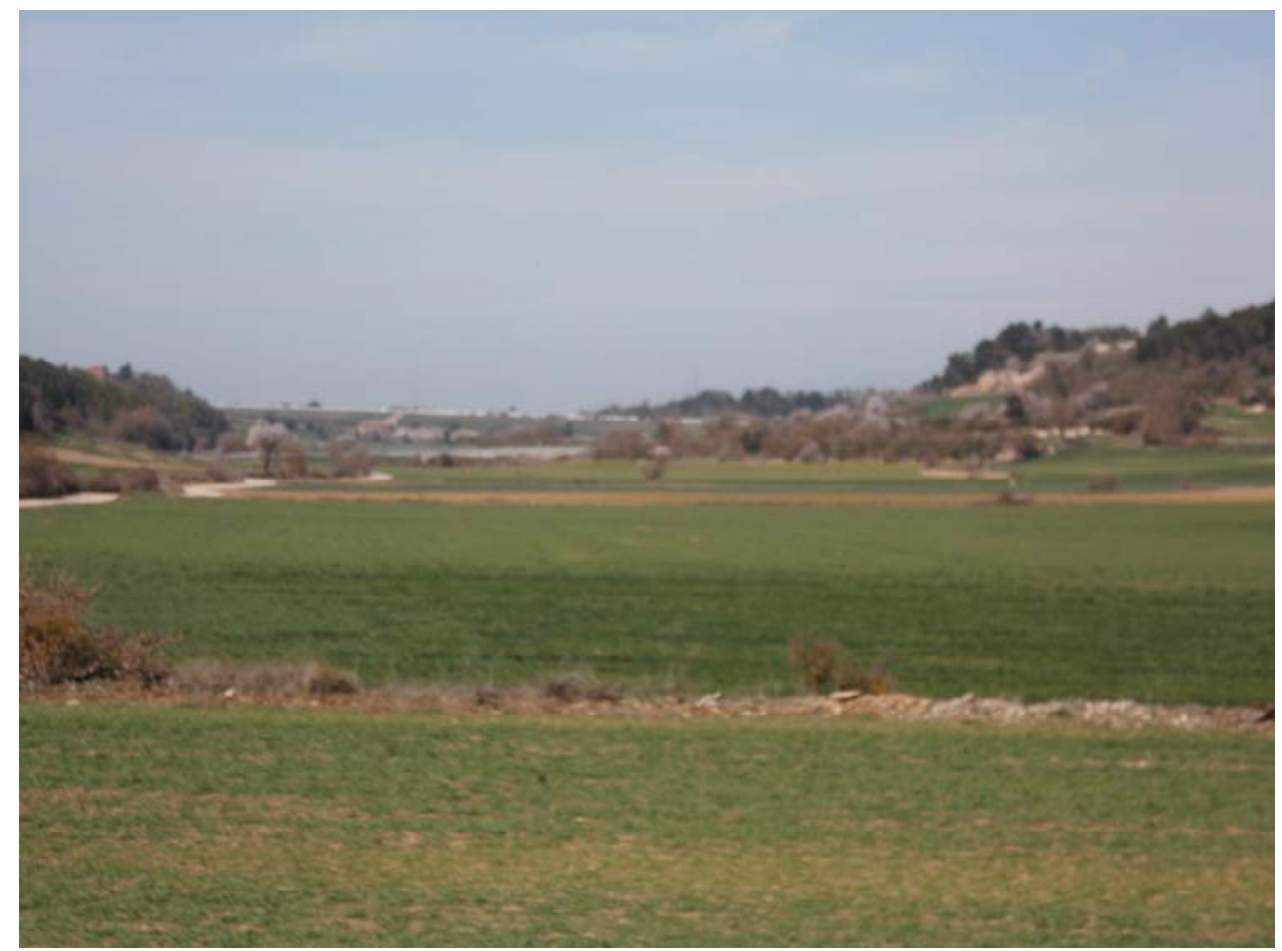

Fotografia 4. Un aspecte de la possible Fosa Tectònica de Ferran - Pujalt

Xaragall.2015 n.2 | Recorregut de recerca geològica i geoambiental per les comarques de l'Anoia (Alta 
Per altra banda, per sobre de la cruïlla de les dues carreteres, es fa força evident una deformació dels afloraments de les roques carbonatades que hem esmentat anteriorment. Així, es veuen una sèrie de fractures i deformació de les esmentades calcaries a uns 50 i 100 metres de la cruilla entre les carreteres B - 102 i N - 141a. (fotografía 5).

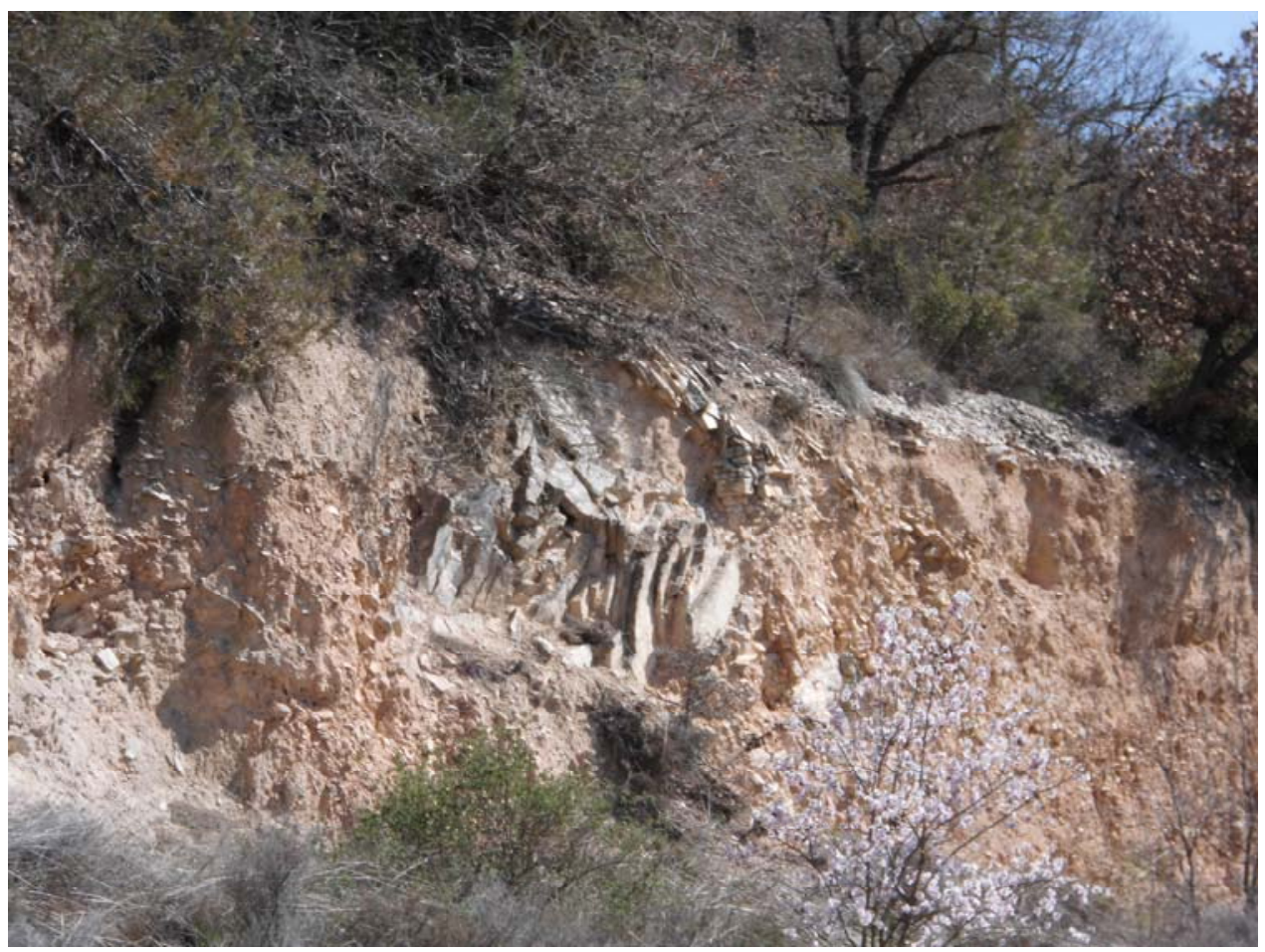

Fotografia 5. Aflorament de les calcàries de la Formació Tàrrega, visiblement deformades. Immediacions de Pujalt, carretera N - 141a

\subsection{Parada 5 - CONDICIONAL. PEDRERA DE CALCÀRIES DE TORRE CATALÀ, CARRETERA DE SANT RAMON A CONILL, (terme municipal de Pujalt, comarca d'Anoia, Alta Segarra Calafina). (Full 391).}

Després de fer la parada anterior, fer un curt recorregut per la carretera $\mathrm{N}-141 \mathrm{a}$, anant cap a llevant (en el sentit de la carretera cap a Calaf). Així, aviat arribarem a una antiga pedrera, recentment reutilitzada. Aquesta es troba a l'esquerra de la carretera, a menys de $1 \mathrm{Km}$ de la parada anterior.

En aquest recorregut, hem continuat trobant afloraments dels materials carbonatats esmentats a les aturades anteriors. Aquests materials pertanyen a la Formació Tàrrega i són els que afloren a l'indret de l'aturada.

Aquí, aquests materials han estat explotats en una antiga pedrera (recentment retreballada). S'han explotat per tal d'ésser emprats com a àrids per a la construcció. (fotografia 6).

Xaragall.2015 n.2 | Recorregut de recerca geològica i geoambiental per les comarques de l'Anoia (Alta Segarra), Segarra i Urgell: des de la Panadella a Estaràs, les Oluges, Tarroja de Segarra, Agramunt i al Pilar 


\subsection{Parada 6 - CONDICIONAL. PEDRERA DE CALCÀRIES DE SANT RAMON, (terme de Sant Ramon, comarca de la Segarra). (Full 361)}

Després de fer l'aturada anterior, cal retornar cap a ponent, per la carretera N-141a. Per aquesta carretera aviat es passarà per Ferran, arribant posteriorment al poble de Sant Ramon. Després d'arribar - hi i de sobrepassar-lo, trobarem una antiga pedrera situada a l'esquerra i a la dreta de la carretera. En aquest indret farem una nova aturada, a uns $7 \mathrm{Km}$ de la parada anterior, aproximadament. En aquest recorregut, hem tornat a entrar a la comarca de la Segarra, pròpiament dita.

En aquest recorregut, hem tornat a trobar els materials esmentats a les aturades anteriors, fonamentalment els nivells de calcolutites del Complex Al/luvial de la Segarra. Tot i així, en aquest indret hi ha una antiga explotació minera, on s'aprofitaven els nivells de les calcàries del Paleogen, de l'Oligocè.

Així, en aquest indret, han estat explotades aquestes calcaries, que pertanyen a la Formació Tàrrega. Al respecte de la pedrera, cal dir que es troba intermitentment en actiu; especialment en els darrers temps (febrer - març del 2014), en els que es veu una certa activitat.

\subsection{Parada 7 - CONDICIONAL. IMMEDIACIONS DE CASTELLNOU DE LES OLUGES, (Castellnou de les Oluges, del terme municipal de Cervera, comarca de la Segarra). (Full 361).}

Després de realitzar l'aturada anterior, cal continuar cap a ponent per la carretera nacional N 141a. Així, aviat arribarem al poble de les Oluges. Des d'aquí, ens caldrà seguir per un camí de terra (en bones condicions), el qual es dirigeix cap el proper poble de Castellnou de les Oluges, tot baixant per la riba dreta del riu Sió. Prop d'aquest poble, podem fer una nova aturada, a uns $6 \mathrm{Lm}$ de I'anteriorment realitzada, aproximadament.

En aquest recorregut, hem continuat trobant afloraments dels materials esmentats a les aturades anteriors. Efectivament, hem anat trobant els nivells carbonatats de la Formació Tàrrega. Aquests són els materials que apareixen per l'indret de la present aturada, prop de Castellnou de les Oluges.

Per d'altra banda, en aquest recorregut, anem seguint de prop el riu Sió, el qual es molt ben aprofitat pels diferents pobles per on discorre, dintre de la comarca natural de la Ribera del Sió, on estem ara situats. (fotografia 7). 


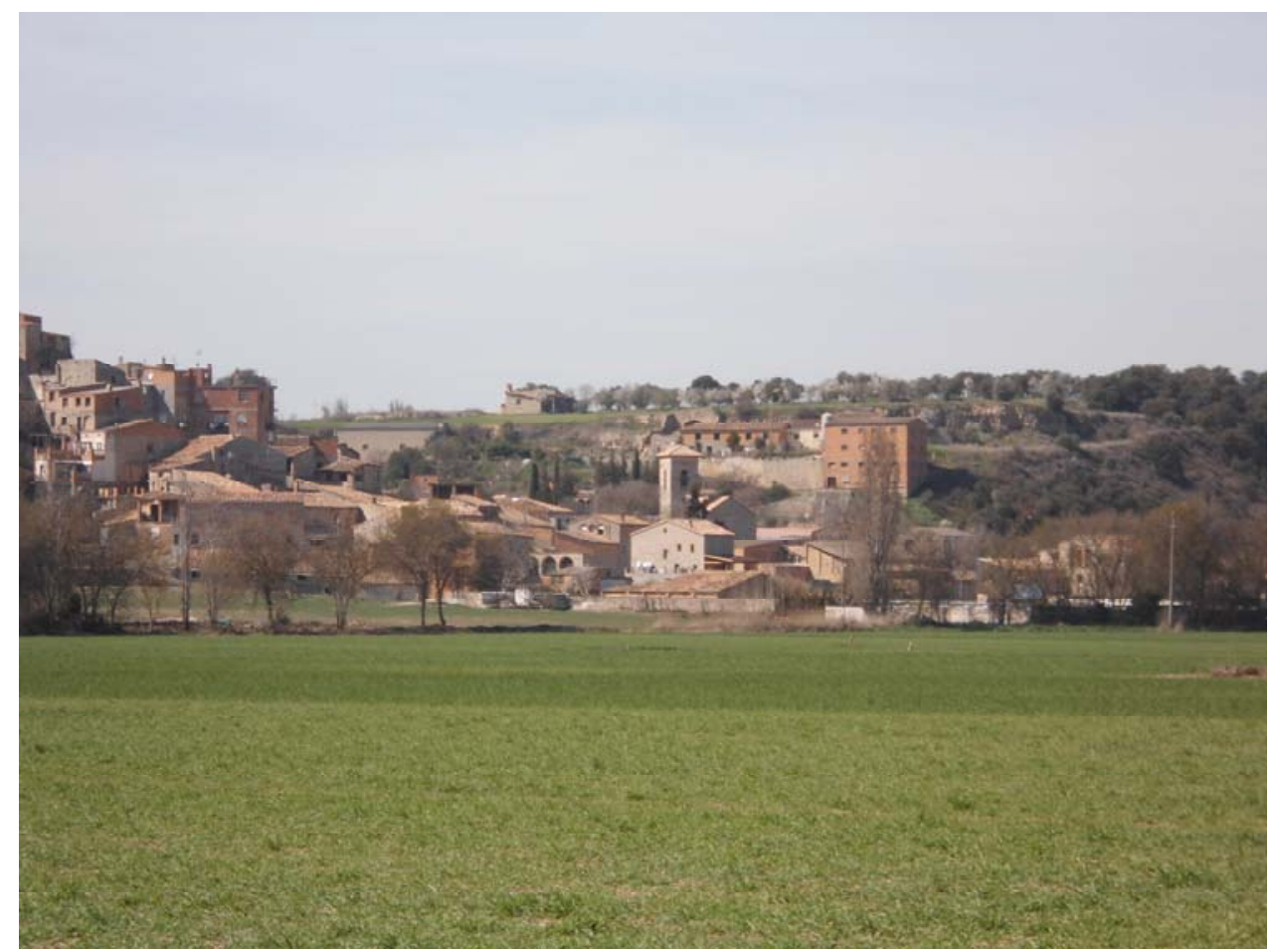

Fotografia 7. El riu Sió a Castellnou de les Oluges

\subsection{Parada 8. PLANA DEL SALOBRER, (Concabella, terme municipal de les Pallargues, comarca de la Segarra). (Full 361).}

Des de la parada anterior, cal continuar pel camí de terra que hem agafat a les Oluges. Així, ara ens caldrà seguir cap als poblets de Malgrat, la Prenyalosa i Tarroja de Segarra, tot seguint el riu Sió, per la seva riba dreta. En arribar al darrer poble esmentat, caldrà agafar la carretera local L - 324, per tal de seguir cap als pobles de Sedó, Riber, Hostafrancs i Concabella. En arribar a les immediacions del darrer poble esmentat, caldrà fer una nova aturada. Així, haurem recorregut uns $8 \mathrm{Km}$ més, aproximadament.

En aquest recorregut, hem anat tallant els materials calcolutítics i carbonatats ja esmentats a les parades anteriors. Tot i així, cada cop es van veient més nivells calcolutítics de tonalitats lleugerament rogenques. De fet, estem començat a trobar afloraments dels materials de la Formació Urgell.

En aquest indret, es palesa una gran plana, que corresponia a una antiga zona endorreica, situada entre Hostafrancs i Concabella. (fotografia 8).

Xaragall.2015 n.2 | Recorregut de recerca geològica i geoambiental per les comarques de l'Anoia (Alta Segarra), Segarra i Urgell: des de la Panadella a Estaràs, les Oluges, Tarroja de Segarra, Agramunt i al Pilar 


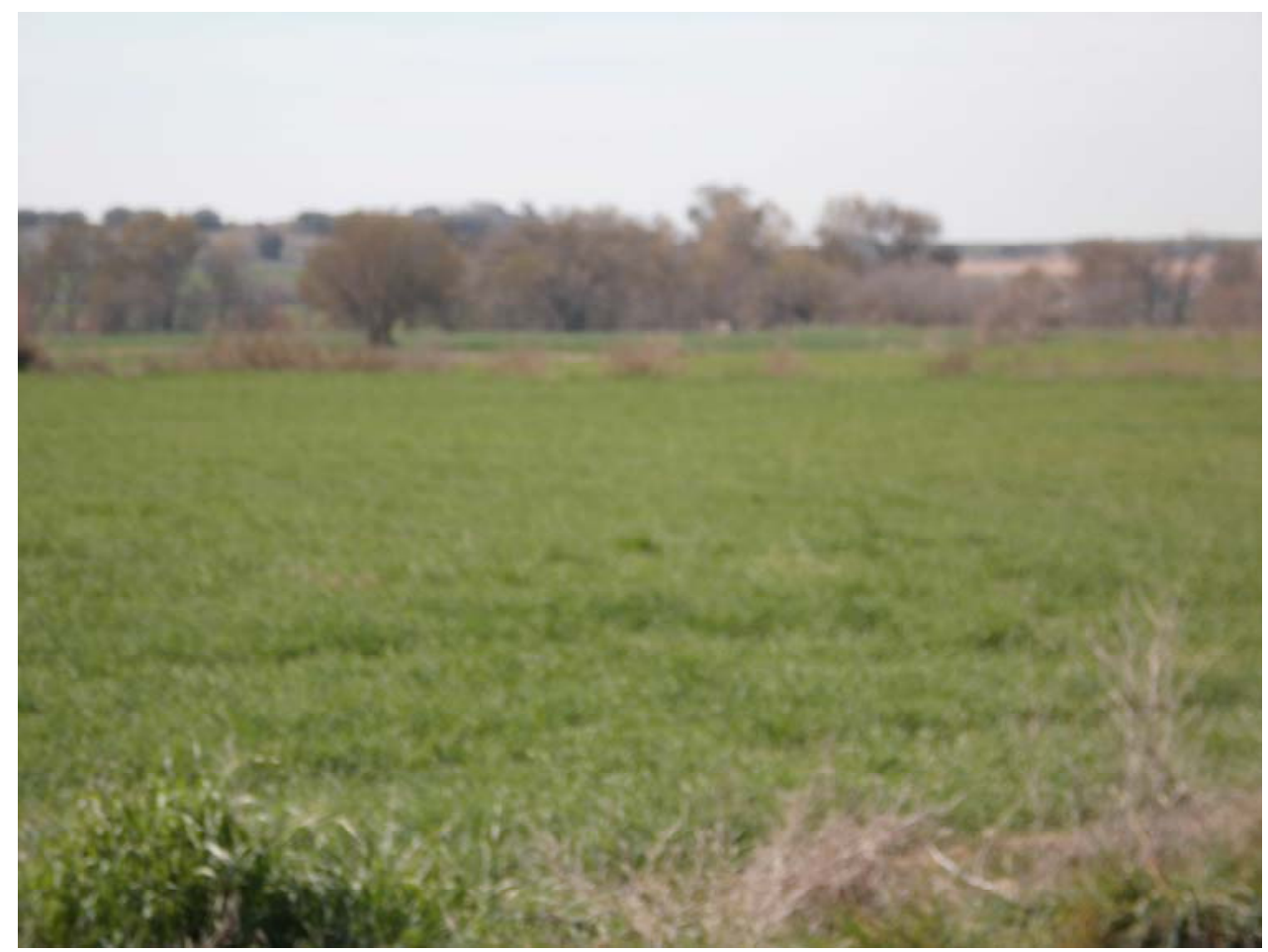

Fotografia 8. Plana del Salobrer, prop de Concabella

\subsection{Parada 9. IMMEDIACIONS DE LA CRUÏLLA DE CASTELLNOU D’OSSÓ, (Castellnou d'Ossó, terme municipal d'Ossó de Sió, comarca del Urgell). (Full 360).}

Des de la parada anterior, cal continuar baixant per la riba dreta del riu Sió, però ara per la carretera $L-304$. Així, ara es passarà pels pobles de: Ratera, les Pallargues i Mont-roig de Segarra. Poc després d'aquest poble s'entrarà a la comarca de l'Urgell, seguint poc després per la carretera $L-303$, passant ara per Bellver d'Ossó (o Bellver de Sió), Ossó de Sió. Poc després s'arribarà a les immediacions de Castellnou d'Ossó. Poc abans d'arribar-hi, podem fer una nova aturada. Així, haurem recorregut uns $6 \mathrm{Km}$, després de fer l'aturada anterior.

En aquest recorregut, hem començat a trobar, cada vegada més, afloraments dels nivells de calcolutites ocres i rogenques, les quals pertanyen a la Formació Urgell, del Complex Al.luvial de la Segarra. Aquests són també els materials que apareixen a l'indret de la present aturada. (fotografia 9)

Xaragall.2015 n.2 | Recorregut de recerca geològica i geoambiental per les comarques de l'Anoia (Alta Segarra), Segarra i Urgell: des de la Panadella a Estaràs, les Oluges, Tarroja de Segarra, Agramunt i al Pilar 


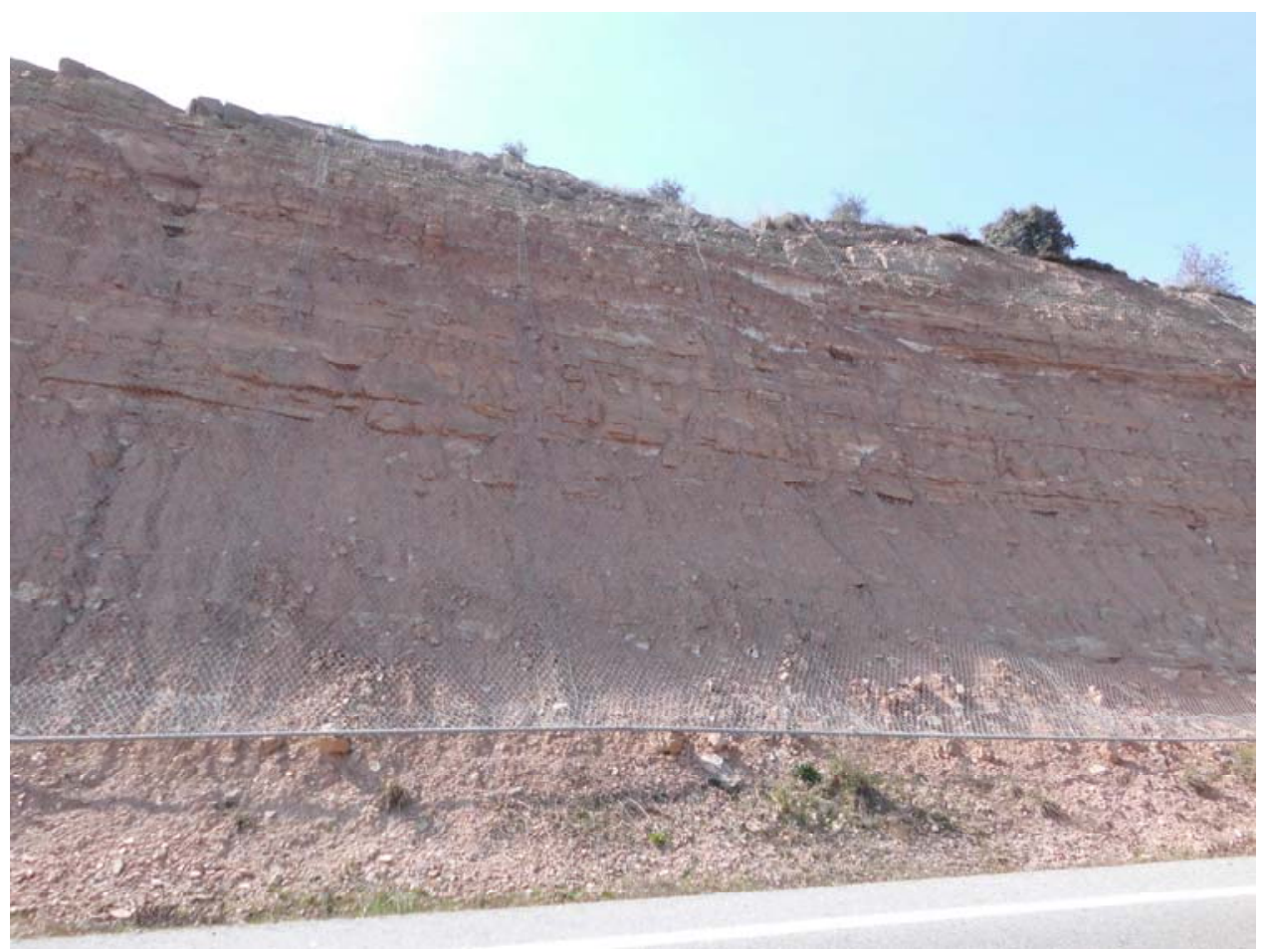

Fotografia 9. Aflorament de les calcolutites de la Formació Urgell. Carretera $L-303$, prop de Castellnou d’Ossó.

\subsection{Parada 10. IMMEDIACIONS DEL PONT SOBRE EL RIU SIÓ, CARRETERA L - 303, (terme municipal d'Agramunt, comarca del Urgell). (Full 360).}

Després de fer l'aturada anterior, cal continuar per la carretera local $L-303$, passant ara per Castellnou d'Ossó, Puigvert d'Agramunt i Agramunt. En arribar a quest darrer poble (la capital de la Ribera del Sió), farem una nova aturada, a uns $5 \mathrm{Km}$ de l'anteriorment efectuada.

En aquest recorregut, hem anat trobant afloraments dels materials esmentats a l'aturada anterior. Aquests materials (nivells de calcolutites ocres, de tonalitats ocres i rogenques) pertanyen a la Formació Urgell.

En aquest indret, es pot veure el riu Sió, que al seu pas per la població d’Agramunt es troba canalitzat.

Xaragall.2015 n.2 | Recorregut de recerca geològica i geoambiental per les comarques de l'Anoia (Alta 


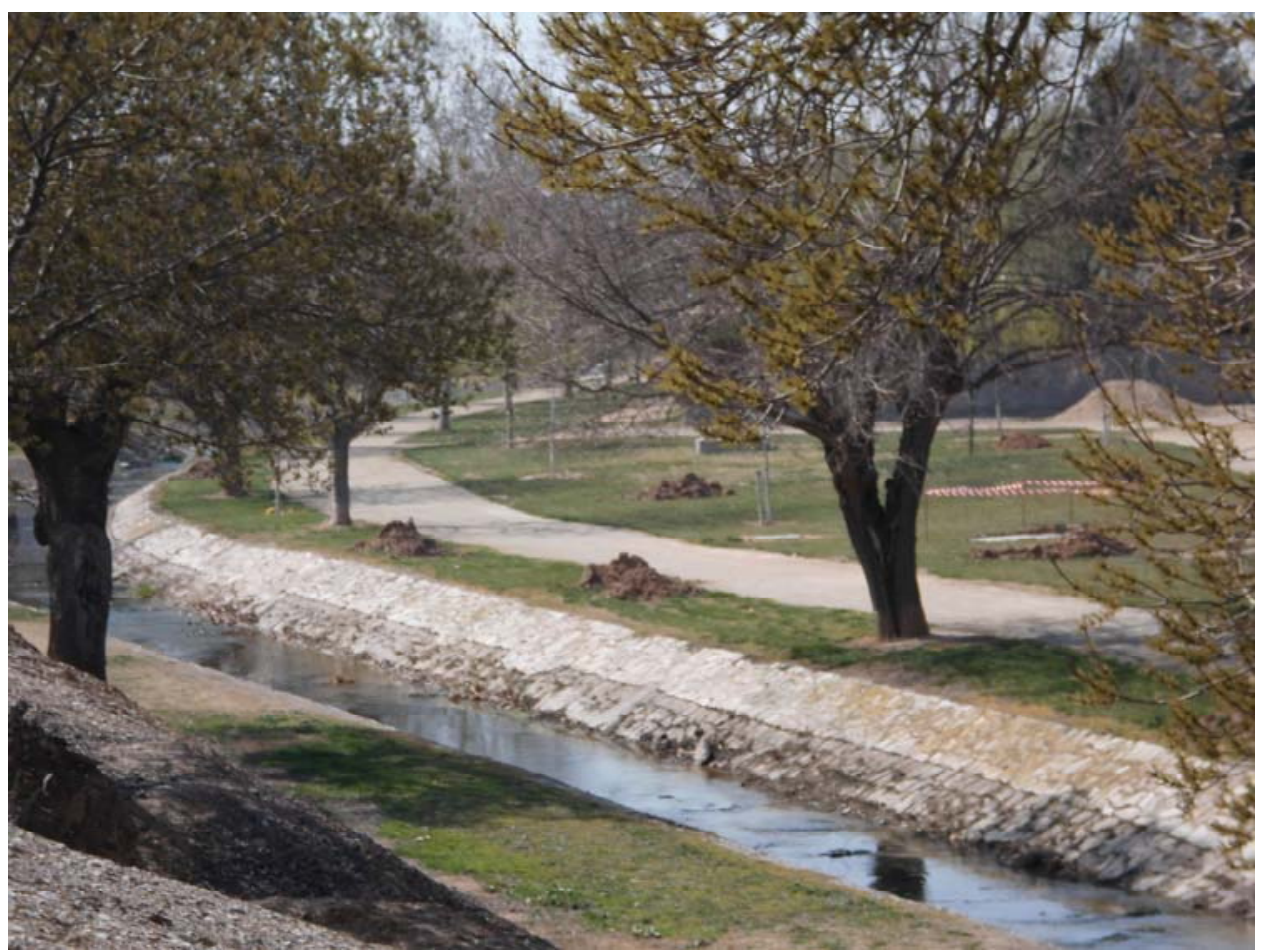

Fotografia 10. El riu Sió canalitzat al seu pas per Agramunt

\subsection{Parada 11. EL PILAR D“ALMENARA, CARRETERA L - 3231, (Almenara, terme municipal d'Agramunt, comarca del Urgell). (Full 360).}

Després de fer l'aturada anterior, cal creuar la població d'Agramunt, per tal d'agafar ara la carretera local L - 3231 (la qual es dirigeix cap el poble de Tornabous). En agafar aquesta carretera local, ens caldrà anar cap el SSW. Seguint aquesta ruta, en arribar a les immediacions del $\mathrm{Km} \mathrm{4}$, farem una nova aturada (la darrera d'aquest itinerari). Així, des de la parada anterior, haurem efectuat un recorregut molt proper als $4^{\prime} 5 \mathrm{Km}$.

En aquest recorregut, hem continuat trobant afloraments dels materials esmentats a les aturades anteriors. Aquests materials, de tonalitats ocres i rogenques pertanyen a la Formació Urgell i tenen un marcat caràcter calcolutític.

Tot i així, en arribar a prop de l'indret de la present aturada, es fan palesos uns nivells de calcolutites blanquinoses i de guixos. Aquests materials que es fan força palesos per sota del Pilar d'Almenara, pertanyen a la Formació Barbastro. (fotografia 11). 


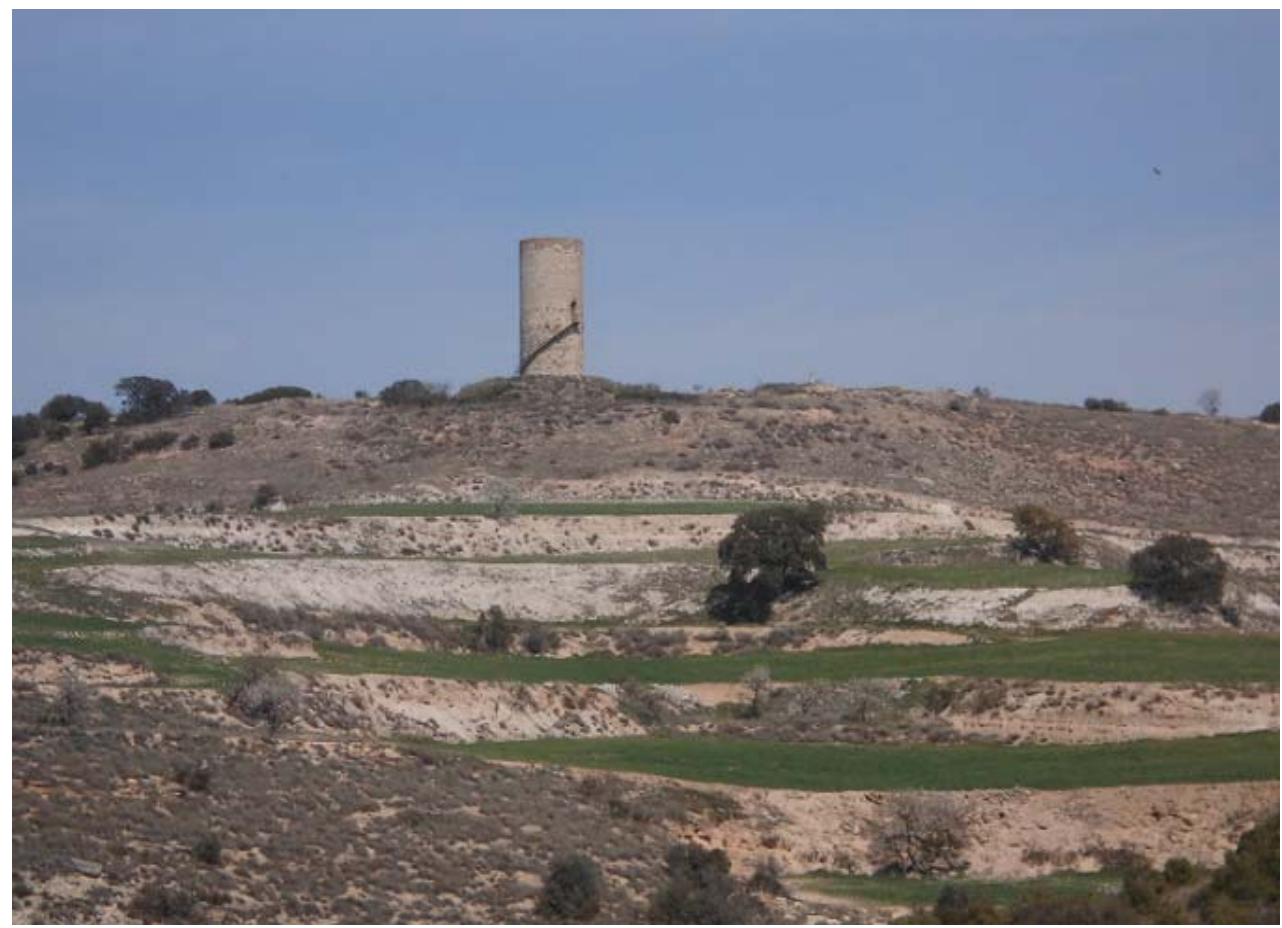

Fotografia 11. Aflorament dels materials blanquinosos de la Formació Barbastro, pels voltants del Pilar d'Almenara

Per altra banda, en aquest darrer tram del recorregut, hem sobrepassat I'Anticlinal del Pilar d'Almenara. En efecte, prop de dalt, hem vist uns materials que tenien un clar cabussament cap el Nord; mentre que baixant cap a Tornabous, es veu un clar cabussament cap el Sud. (fotografies 12 i 13).

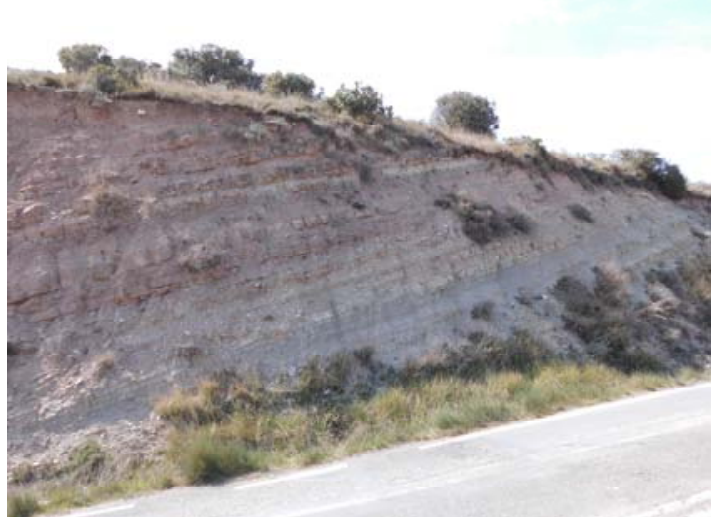

Fotografia 12. Cabussament cap el Sud, baixant cap a Tornabous. Anticlinal del Pilar d'Almenara

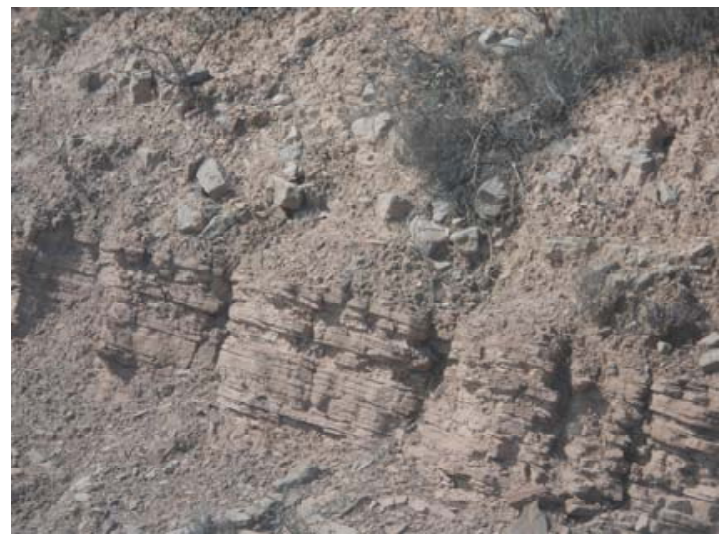

Fotografia 13. Cabussament cap el Nord, baixant cap a Agramunt. Anticlinal del Pilar d'Almenara

En aquest indret finalitza el recorregut de l'itinerari

Xaragall.2015 n.2 | Recorregut de recerca geològica i geoambiental per les comarques de l'Anoia (Alta Segarra), Segarra i Urgell: des de la Panadella a Estaràs, les Oluges, Tarroja de Segarra, Agramunt i al Pilar 


\section{Bibliografia}

GUIMERÀ, J. et altri (1992).- Geologia (II), Història Natural dels Països Catalans, Vol.2, 547 pag. Enciclopèdia Catalana, S.A. Barcelona.

MATA - PERELLÓ, J.M. (1985).- Depressió de l'Ebre ?, Depressió Central ?. Revista Dovella, $\mathrm{n}^{\circ} 15, \mathrm{pp} .45-48$. Manresa.

MATA-PERELLÓ, J.M. (1990).- Inventari Mineralògic de la comarca d'Anoia. Revista Xaragall, $\mathrm{n}^{\circ} 24,40$ pag. Manresa.

MATA-PERELLÓ, J.M. (1991).- Els Minerals de Catalunya. Arxius de la Secció de Ciències, t. XCIII, 442 pag. Institut d’Estudis Catalans. Barcelona.

MATA-PERELLÓ, J.M. (1999).- Recorregut de recerca geològica i mineralògica per les comarques de la Noguera, del Pla d'Urgell i de I'Urgell: des de Barbens i Penelles a Cubells; i des d'Artesa de Segre a la Guàrdia de Tornabous. Inèdit. 15 pàgines. Manresa

MATA-PERELLÓ, J.M. (2007).- Recorregut de recerca geològica, minera i mineralògica per les comarques de l'Anoia, l'Alta Segarra calafina (Anoia) i de la Segarra: des de la Panadella a Sant Martí de Sesgueioles, Calaf, Durfort i a Castellfollit de Riubregós. Inèdit. 10 pàgines. Manresa.

MATA-PERELLÓ, J.M. (2014).- Recorregut de recerca geològica i geoambiental per la comarca d'Anoia (subcomarca de I'Alta Segarra): des de la Panadella a Sant Martí Sesgueioles i a Calaf. Inèdit. 10 pàgines. Manresa.

RIBA, O. et altri (1976).- Geografia Física dels Països Catalans, Edit. Ketres, 254 pàgines. Barcelona. 